\title{
Results of 20 years of searching and studying gas hydrates in Lake Baikal
}

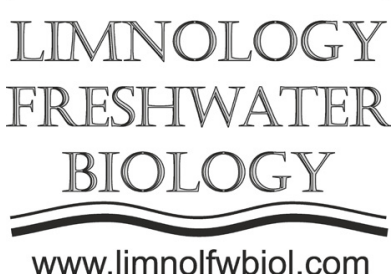

\author{
Khlystov O.M. \\ Limnological Institute, Siberian Branch of Russian Academy of Science, Irkutsk, Russia
}

ABSTRACT. The 20-year history of studying the near-surface accumulations of gas hydrates in Lake Baikal revealed the same pattern of their formation and distribution in both marine environments and a freshwater body. However, Lake Baikal has its own features of the coexistence of gas hydrates with different structures and the causes of occurrence of hydrate-bearing mud volcanoes, which have been found and described nowhere in the world.

Keywords: Lake Baikal, gas hydrates, mud volcanoes

For more than 50 years, a comprehensive study of natural gas hydrates has been conducting in the World Ocean. Their deep and near-surface (sub-bottom) accumulations are distinguished. All of them were discovered on the seabed in the zones of sedimentation and oil and gas generation depocentres. Along the tectonic faults that control near-surface accumulations of gas hydrates, there are discharges of gas and gas-saturated fluids in seeps and mud volcanoes. Mechanisms of formation of gas hydrates and geological structures interconnected with each other were determined. All known gas-hydrate crystal structures (SI, SII, H) that are formed, depending on the structure and composition of gases, were discovered in seas (Kvenvolden, 1999; Subramanian et al., 2000; Bohrmann and Torres, 2006; Sloan and Koh, 2008).

Based on the geological and geophysical data obtained using side-scan sonar, continuous seismoacoustic profiling, single-beam and multibeam echosounding, geological testing and visual observations from the MIR deep-sea manned submersibles, marine methods and approaches were adapted or new ones were developed to search for gas hydrates in the bottom sediments of a freshwater lake. Since the discovery of the first near-surface (subbottom) gas-hydrate accumulations in Lake Baikal in 2000 , these data have become basic for substantiating their geological and geophysical search indicators (Khlystov et al., 2013). Thanks to these indicators, 60 hydrate-bearing structures have been discovered by 2020 . They include 48 mud volcanoes and alike structures (hydrate mounds), 11 seeps and 1 pockmark.

Externally, gas hydrates of different geological structures are almost the same. Everywhere, there are massive, lenticular, vein and granular gas hydrates (Khlystov et al., 2013). Two of the three known types of cubic gas hydrates were found in the bottom sediments of the lake: SI structure hydrates of biogenic methane and SII structure hydrates of the biogenic methane and thermogenic ethane mixture (Kida et al., 2006). The latter ones always have a granular structure. Only in Lake Baikal, these structures co-exist simultaneously in the same section, contacting with each other (Hachikubo et al., 2009; Manakov et al., 2013). Findings of large autogenic carbonate crusts and nodules in the zones of gas-hydrate manifestations, which are generally untypical of ultra-fresh lakes, are unique for Lake Baikal (Krylov et al., 2008).

Based on the comprehensive studies and features of the formation and destruction of gas hydrates in the freshwater low-temperature lake under-saturated with methane, we substantiated, tested and patented a simple and cheap method for gas production from the near-surface accumulations of gas hydrates (Khlystov et al., 2011).

We proved the primary role of the Baikal gas hydrates at the initial stage of mud volcanism on the lake's floor, which is untypical of the marine environments. In Lake Baikal, the presence of mud volcanoes is directly associated with the destruction of gas hydrates at the lower boundary of their stability zone (not deeper than $450 \mathrm{~m}$ below the bottom) due to tectonic activity and the influx of warm fluids rather than with the overburden pressure areas at depths of several kilometres, as shown for marine and terrestrial mud volcanoes. Owing to this, we substantiated a previously unknown type of mud volcanism with shallow roots, which was called a Baikal type (Khlystov et al., 2019).

Like in seas, tectonic faults control the distribution of hydrate-bearing structures on the floor of Lake Baikal. However, migration pathways of gas- 

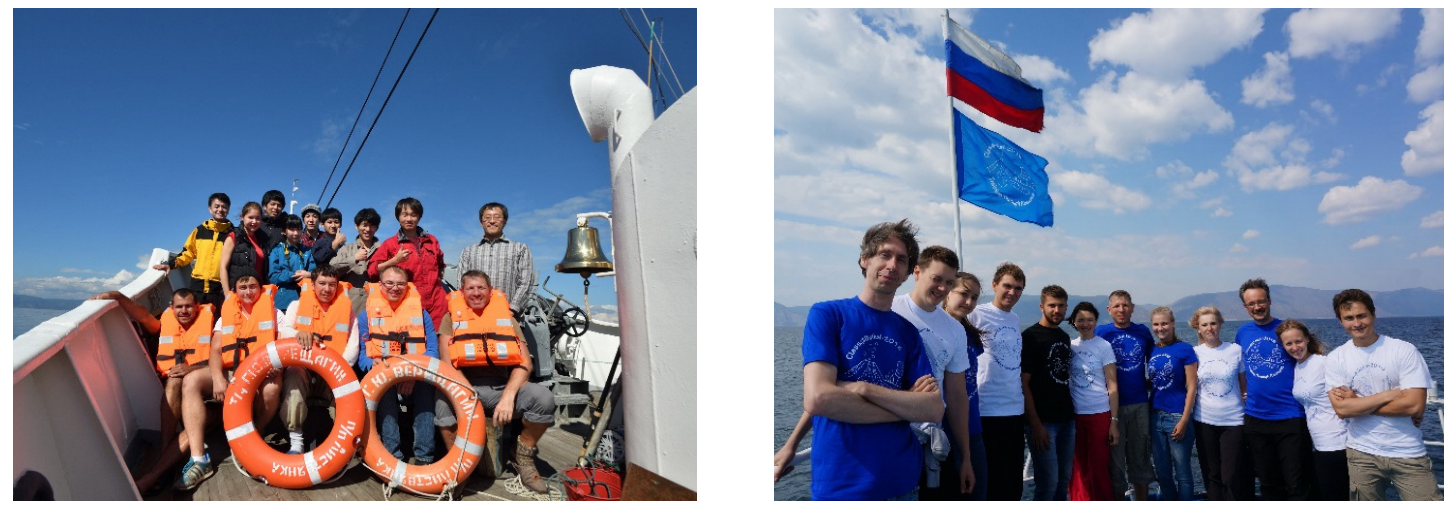

Fig. Group photographs of scientists, professors and students participating in the MHP (left) and Class@Baikal (right) projects

saturated fluids pass through not only weakened zones of the main rift-forming and secondary faults in deep basins but also the permeable strata on their slopes along the anticlinal landforms (apical parts of dividing crests). We determined that delta-front sediments of rivers and other sedimentation depocentres are the sites and sources of gas-saturated fluids in the middle parts of depressions, as well as the near-surface occurrences of ancient sedimentary strata - at the eastern flank.

The Baikal gas hydrates, thanks to their diversity, availability and low cost of the study compared to the marine ones, not only provide new discoveries in this field of geology but also serve as a visual aid or a study subject of learning through training for students and postgraduates as well as for improving the qualification of the specialists of oil and gas industries from various regions of Russia as well as countries of Europe and Asia. For instance, there are the following long-term programmes for studying gas hydrates and learning on their example, which take place at Limnological Institute SB RAS: Multi-phase Gas Hydrate Project (MHP) (since 2009) together with Japanese collaborators and students; the Class@Baikal Floating University (since 2014) together with scientists, professors and students from Moscow State University, various countries of Europe and specialists from oil and gas companies (Fig.).

\section{Acknowledgements}

This study was supported by the LIN SB RAS State Task No. 0345-2019-0007.

\section{References}

Bohrmann G., Torres M.E. 2006. Gas hydrates in marine sediments. In: Schulz H.D., Zabel M. (Eds.), Marine Geochemistry. Berlin/Heidelberg, pp. 481-512.
Hachikubo A., Khlystov O., Manakov A. et al. 2009. Model of formation of double structure gas hydrates in Lake Baikal based on isotopic data. Geophysical Research Letters 36(18). DOI: $10.1029 / 2009$ GL039805

Khlystov O.M., Nishio Sh., Grachev M.A. 2011. Russian Federation Patent 24123376, E21B43/01. Method for oil production from gas hydrates of bottom sediments. Byul. 5 . (in Russian)

Khlystov O.M., De Batist M., Shoji H. et al. 2013. Gas hydrate of Lake Baikal: discovery and varieties. Journal of Asian Earth Sciences 62: 162-166. DOI: 10.1016/j. jseaes.2012.03.009

Khlystov O.M., Poort J., Mazzini A. et al. 2019. Shallow-rooted mud volcanism in Lake Baikal. Marine and Petroleum Geology 102: 580-589. DOI: 10.1016/j. marpetgeo.2019.01.005

Kida M., Khlystov O., Zemskaya T. et al. 2006. Coexistence of structure I and II gas hydrates in Lake Baikal suggesting gas sources from microbial and thermogenic origin. Geophysics Research Letters 33: 1-4. DOI: 10.1029/2006GL028296

Krylov A., Khlystov O., Zemskaya T. et al. 2008. First discovery and formation process of authigenic siderite from gas hydrate-bearing mud volcanoes in fresh water: Lake Baikal, eastern Siberia. Geophysical Research Letters 35. DOI: 10.1029/2007GL032917

Kvenvolden K.A. 1999. Potential effects of gas hydrate on human welfare. Proceedings of the National Academy of Sciences of the United States of America 96(7): 3420-3426. DOI: 10.1073/pnas.96.7.3420

Manakov A.Yu., Khlystov O.M., Hachikubo A. et al. 2013. A physicochemical model for the formation of gas hydrates of different structural types in K-2 mud volcano (Kukuy canyon, Lake Baikal). Russian Geology and Geophysics 54(4): 475-482. DOI: 10.1016/j.rgg.2013.03.009

Sloan E.D. Jr., Koh C.A. 2008. Clathrate hydrates of natural gases. Third ed. Boca Raton: Taylor and Francis.

Subramanian S., Ballard A.L., Kini R.A. et al. 2000. Structural transitions in methane plus ethane gas hydrates - Part I: upper transition point and applications. Chemical Engineering Science 55(23): 5763-5771. DOI: 10.1016/ S0009-2509(00)00163-9 